\title{
Political Parties and the Law
}

Howard A. Scarrow, State University of New York Stony Brook

Political scientists have long been aware of the relationship between American political parties and the law. That relationship began prior to the turn of the century when states introduced the government-printed Australian ballot, an innovation which required states to determine the standards for parties to gain access to that ballot. Those early laws set the stage for the later Progressive-inspired laws imposing on officially recognized parties a variety of regulations, most notably the requirement that the parties nominate their candidates through the process of primary elections.

In recent years political scientists have supplemented this traditional focus on the historical impact of state laws on party development with a new focus: the impact on parties of decisions rendered by the judiciary, especially by the United States Supreme Court. It is this later development which inspired the Political Organizations and Parties Section of the American Political Science Association to sponsor a workshop on "Parties and the Law" at the 1995 Annual Meeting of the Association. Three of the papers presented at that workshop are included in this issue of The American Review of Politics.

\section{Three Types of Plaintiffs}

Most Supreme Court cases relating to political parties can be classified according to the type of plaintiff seeking relief. Sparking most interest among political scientists have been those cases brought in recent years by national, state, and local party organizations claiming that state election laws have violated their rights of association guaranteed by the First and 14th Amendments. In several notable cases the Court has ruled that party organizations have such rights, rulings which would seem to stand in contrast to the Court's earlier rulings outlawing "white primaries," and which may seem to call into question the constitutionality of many of the Progressiveinspired laws enacted in the early part of the century. The cases involving parties' association rights are discussed in the paper by Dan Lowenstein.

HowARD A. SCARROW is Professor of Political Science at the State University of New York Stony Brook.

The American Review of Politics, Vol. 16, Winter, 1995: 317-320

๑1995 The American Review of Politics 
Like party organizations, party voters have sought relief from state laws or practices seen as depriving them of their First Amendment rights of association. In one of the earliest cases several New York voters tried unsuccessfully to have the courts declare unconstitutional New York's closed primary law with its long lead time required for a voter to change party registration (Rosario $v$. Rockefeller). In this and similar cases the defendant could realistically be viewed as being not an official representing the state government (e.g., Rockefeller), but rather one or both of the two major parties. Closed primary requirements exist only because those parties, which control state government, want them to exist.

It is this failure to distinguish between the various components of party-party in the government, party organization outside of government, and party in the electorate-which Lowenstein identifies as one of the major weaknesses of the Supreme Court's various rulings concerning the association rights of parties. The partisan gerrymandering cases could also easily be seen as a conflict between the rights of two components of party-i.e., rights of partisan voters of one party weighed against the rights of party-ingovernment of the other. But the Court, though ruling that partisan gerrymandering does present a justiciable claim (Davis $v$. Bandemer), has not formulated the conflict in this fashion.

The components-of-party perspective could also be applied to the Court's several rulings on party patronage. In these cases a state or local government's right to award jobs on a partisan patronage basis has been weighed against the free speech and association rights of job applicants denied employment because of their support of the "out" party. The Court continues to be sharply divided in weighing these conflicting patronage claims, no doubt in part because the dissenting justices (Powell earlier, Scalia today) have reasoned that party-in-government is, indeed, the defendant. A paper discussing the patronage cases was presented at the workshop by Professor Cynthia Bowman of the Northwestern University School of Law. The published version will be found in the March 1996 issue of The Journal of Law and Politics.

The third type of plaintiff claiming rights of association have been independent candidates and candidates of minor parties. In these cases, too, the defendant, though officially a state official, should probably be seen as being one or both of the major parties. The two major parties usually prefer to have the ballot to themselves, and their members in state legislatures have been responsible for the often formidable state ballot access requirements. The history of ballot access laws and the Court's assessment of them are the focus of the paper by Richard Winger. 


\section{National Laws}

The paper by Douglas Amy serves as a useful reminder that the explanation for the United States having only two major political parties lies less with ballot access laws than with state and national laws, which mandate the use of the single member district, plurality election system for electing legislators. Decisions by the Supreme Court in cases arising under the Voting Rights Act have given new credence to arguments that the United States should change its election system to one which would encourage the creation of more than two major parties. If "majority-minority" Congressional districts created under the Voting Rights Act are undesirable and/or unconstitutional, then why not change to an election system which would allow all minority voting blocs to "elect candidates of their choice?"

The foregoing example suggests that the topic of "political parties and the law" may now have reached a new stage: rather than state laws being the focus of inquiry, political scientists might now begin to turn their attention to the impact on parties of national laws. At the very moment of this writing (March, 1996) the Supreme Court has handed down a decision holding that the Voting Rights Act applies to political party nominating conventions; procedures used by the Virginia Republican Convention will have to be cleared with the Justice Department (Morse v. Republican Party of Va.). Obviously the association rights of political parties are subject to limits imposed by national as well as by state laws and, as this ruling shows, are not absolute.

Another Voting Rights Act case in the 1995-96 term also has the potential of affecting the party system. In its continuing struggle with the constitutionality of majority-minority districts the Court will again be presented with an opportunity it has thus far ignored. The Court could easily reiterate its holding that partisan gerrymandering can usually survive court challenge and, indeed, that such gerrymandering may sometimes serve a benign purpose (Gaffney v. Cummings). Thus while "majority-minority" districts may be unconstitutional, purposefully designed "majority-Democrat" districts are presumably permissible. In view of the fact that Justice O'Connor has held that

\footnotetext{
"The preservation and health of our political institutions, state and federal, depends to no small extent on the continued vitality of our two-party system, which permits both stability and measured change (Davis v. Bandemer, 145),
}

and that Justice Scalia has expressed similar sentiments, a pro-party resolution of the Court's problems with racial gerrymandering might seem a logical one. Even justices who have supported majority-minority districts, 
such as Justice Ginsberg in her dissent in Miller v. Johnson, have curiously refused to refer to the legitimate tradition of partisan gerrymandering; to buttress her argument that the practice of gerrymandering has long historical roots, she refers only to the practice of creating ethnic districts for Italians, Irish, and so forth.

Another element of national law affecting political parties has been the campaign finance law(s). The aspect of these regulations which most disturbs those who champion the role of parties in a democracy is that, as interpreted by the Court, organized interest groups are able to spend unlimited amounts of money in support of their preferred candidates (so long as expenditures are made "independent" of the candidates), while political parties are not. In the 1995-96 term the Committee for Party Renewal filed an amicus brief urging that the Court place parties on an equal footing with interest groups.

As will be seen from these two examples of cases currently before the Court, the potential impact of pro-party rulings in cases arising under national law far exceed the modest impact of the rulings which have recognized the parties' First Amendment rights of association.

\section{CASES}

Davis v. Bandemer, 478 U.S. 109 (1986).

Gaffney v. Cummings, 412 U.S. 735 (1973).

Miller v. Johnson, 63 U.S.L.W. 4726 (1995).

Morse v. Republican Party of Virginia, Docket 94-203 (1996).

Rosario v. Rockefeller, 410 U.S. 752 (1973). 